\title{
Articles \\ Tax Absence in Relation to Taxation of Digital Services
}

\author{
Tereza Čejková*
}

* Tereza Čejková, Mgr. PhD candidate at the Department of Financial Law and Economics, Faculty of Law, Masaryk University, the Czech Republic, email: ter.cejkova@gmail.com

\begin{abstract}
In the area of taxation of business corporations operating in several different countries, there is a problem arising with the identification of the tax residence of the liable entity. With the expansion of the so-called digital business, where entrepreneurs often do not have a physical headquarters or business units, this problem is becoming more common. Efforts to introduce a digital tax within the Member States of the Organisation for Economic Co-operation and Development and the European Union are accompanied by efforts to address this issue through various legislative acts. This article explains how the problem of identifying tax residence arises, why it is undesirable and describes possible solutions.
\end{abstract}

Keywords: tax residency, digital tax, CCCTB

\section{Introduction}

Taxation of digital business activities has been a topic discussed for several years both by national authorities and at the level of the European Union or Organisation for Economic Co-operation and Development (hereinafter OECD). There are many reasons why taxing services such as online advertising, digital brokerage, user data collection and more is so demanding. Probably, the most important of these is the fact that these services are usually offered by business entities, which, however, exist only in the virtual sphere. Digital technologies allow entrepreneurs to operate without the need for a physical location in a specific location. This can be problematic in determining the correct tax jurisdiction. For the purposes of this paper, this phenomenon of non-existence of real residence will be called tax absence.

These flexible entrepreneurs travel, work for a Hungarian client in a café in Jakarta or in an alpine chalet (provided a quality internet connection, of course). They communicate with customers via the Internet and offer their services and products to any corner of the world. This is possible because, due to the nature of such a business, there are no additional costs associated with long-distance deliveries. This is a significant advantage over the sale of "traditional" goods and services, which contributes to the growing popularity of this type of business. 
In case of employees, their movement is not a particularly problematic element. Due to the mass spread of modern technology, the ability to work remotely from home or anywhere else has become a standard rather than a bonus. ${ }^{1}$ If an employee does his/her job well, he/she gets his/her salary and tax matters lie with the employer, who is subject to tax jurisdiction depending on his/her registered office. (Čejková, 2019, p. 39) So, we have a new way of doing business that generates more and more profit, and in contrast a relatively traditional system of taxation, which cannot comprehensively cover these activities. At first glance, a simple solution could be offered - the principle of domicile, where the tax rules of the state in which the entrepreneur has his/her registered office or permanent residence apply. However, the situation is more complicated, mainly for two reasons:

- Constant movement of the entrepreneur and the related use of his/her income in different countries. Although the entrepreneur has his/her registered office, which is usually a condition for obtaining a business license, due to the constant movement, his/her activity is affected by a number of factors. One of them is contributing to various national economies, for example through VAT, using the services of an internet provider and more. It also makes it easy for him/her to find the country with the most favourable tax regime for its official seat, which again leads to a decrease in the income of the state to which the entrepreneur has a real relationship. This problem is particularly evident in the taxation of profits.

- Concerning customers from different countries, in case of digital content, such as Internet advertising or part of application code, etc., it is very difficult to determine who the end customer is. Under current EU rules, VAT is paid to the country of final consumption of the product. However, this data is often not available or of low quality and is easily falsified.

- Both the OECD and the European Union have long been working to bring these mobile entrepreneurs under control in terms of taxation. In this paper, I will try to explain exactly what the problem of tax absence in relation to the digital taxation is and how these international organisations try to fight it. We will focus in particular on the actions of the European Union, because its regulation is closer to us by its nature and we will feel its impact rather immediately.

\section{Literature overview}

The research is based mainly on the analysis of prepared legal regulation both at the national and the EU level. Academic literature was used to explain important concepts and was supported by internet articles written by personalities knowledgeable in the tax environment.

\footnotetext{
This article is being written at the time of the coronavirus outbreak crisis (2020). At this time, we are all best aware that the possibility of working remotely is applicable to professions for which, for example, only ten years ago, it would have been unthinkable.
} 


\section{Research}

The work will be based mainly on the analysis of valid and still-being-prepared community legislation. The explanatory method will explain the essence of tax absence and will provide practical examples of situations where this causes real problems - in this part, deduction will be used. The hypothesis, which will either be confirmed or refuted in the end, is the question of whether the forthcoming rules of the European Union are sufficient to capture the problem and whether such a solution is sustainable in the future considering the issues related to globalisation.

\section{Discussion}

The first question we need to answer is how the subject becomes absent for tax purposes. To do this, it is first necessary to explain the essence of digital business - who is a liable entity and on what basis does tax liability arise. It is also necessary to explain the principle of tax residence. It is true that tax residence is a notorious concept not only among experts, but also among the non-professional public. However, it includes aspects that may make it impossible to classify the entity in the relevant tax jurisdiction.

The problem may be visible from the definition of the liable subject, which is not easy to grasp. This subject provides digital services. For the time being, the regulations provide for the following activities, the trading of which is to be subjected to a digital tax:

1. services consisting of the placing of targeted advertising on a digital interface aimed at users of that interface, and related ancillary services

2. services consisting of the use of multilateral digital interfaces, which allow users to conclude a transaction between users of the multilateral digital interface, or otherwise use the multilateral digital interface

3. sale of data collected about users (Explanatory Memorandum to the Digital Tax Act)

Ad 1. The person who is liable to pay the tax is in this context usually the end customer. We consider a customer to be a person who pays for a service to benefit from it. In case of advertising, such as banners, automatically triggered videos when opening an Internet article, product placement, etc. the customer is the contracting party. Significantly, this type of advertising is not universally accessible to all Internet users. Digital advertising, especially on social networks, responds to user data collected using so-called cookies. ${ }^{2}$ These are processed in such a way as to recognise the user's preferences and show him/her only such advertising that may be potentially interesting for him/her, and ideally even at the moment when he/she may consider buying a given product or service.

\footnotetext{
See, for example, Google's policy: A cookie is a short text file that a webpage you visit sends to your browser. It allows the site to record information about a user's visit, such as their preferred language and other settings. "Cookies are used for a variety of purposes. For example, we use them to store your SafeSearch preferences, to select relevant ads, to monitor the number of visitors to a page, to facilitate the registration of new services, to protect your data, or to store ad settings." Accessible at: https://policies.google.com/technologies/cookies?hl=en.
} 
For this type of supply, we can pose a question whether we can also include the promotion of products carried out by bloggers and via social networks. Although this activity is also inherently performed in the Internet environment through the transmission of digital signals, it is not characterised by the need for active code generation. It is then not even offered to Internet users on the basis of their preferences, as explained above, but to so-called followers. ${ }^{3}$ The advertisement itself is then more traditional in nature, when, in principle, the benefits of the product are communicated to the public orally or in writing. However, even if this type of advertising does not fall into the given category, in both cases we know how to identify the obligated subject. However, what can be confusing is that the regulations do not take into account whether the advertising service provider owns the digital interface on which the advertisement appears (the Digital Tax Directive proposal). Where an advertising service provider places advertising on an interface which has been left to him/her for use, the person who provided that part of the interface should not be liable to tax.

Ad 2. Very similar in character to digital advertising are services consisting in making multifaceted digital interfaces available to users, which in the current state of legislation can be described as "intermediary services". Basically, it is the operation of the Internet interface - the web, applications, databases, etc., and their provision to the general public. This includes e-shops, search engines, interactive and gaming websites, as well as comprehensive social networks that allow users to search for other users and interact between each other, and which may also allow related deliveries of goods or services directly between them. Here, the fact that the legislation does not take into account who owns such a platform can cause even more complications than in the advertising discussed above.

Quite specific are the Internet interfaces enabling the execution of direct transactions using a payment gateway (application) and some more advanced social networks. For a person without at least a general knowledge of the technical background of these platforms, it can be very difficult which part is subject to tax and which is no longer. The Directive on a common system of taxation for digital services as income tax on the supply of certain digital services (hereinafter "the Digital Tax Directive") seeks to provide the following explanation: "...multifaceted digital interfaces allowing users to search for and interact with other users, an aspect that allows service providers to benefit from network effects. The ability of these interfaces to establish connections between users distinguishes intermediary services from other services, which can also be considered facilitating user interaction, but through which users cannot contact each other unless they have previously made contact using other means, such as instant messaging services, messaging. Creating value for these other services, which can generally be defined as communication or payment services, consists of developing and selling supporting software that enables this interaction and is less tied to user involvement. Communication or payment services therefore do not fall within the scope of the tax." This means that, although the operation and provision of such an internet platform for use is subject to taxation, applications for the exchange of messages between users and payment gateways enabling financial transactions do not fall

In the social networking environment, a "follower" is a user who subscribes to content shared by another specific user by an active action. 
within the scope of the tax. The provision of digital content itself is also excluded from the scope. These services will be taxed according to a special law.

Here we are getting closer to the sense of the problem. If it does not matter which entity owns the internet platform as a whole, and at the same time its various parts are taxed separately, in addition to different tax rules, a multi-layered system is created which will be difficult for tax administrators to decipher. At the same time, it is difficult to determine what actually falls within the scope of taxation. The tax administrator, or the auditor, will most likely be required to have a relatively extensive technical knowledge. Another possibility is to involve experts, which would, however, significantly increase the cost of collecting and administering the tax, in which case we could discuss the effectiveness of its introduction and collection at all.

Ad 3. The commodity of the twenty-first century is data. ${ }^{4}$ They are traded for a variety of purposes. They help entrepreneurs create content much better targeted to their potential customer, identify them in the crowd, but also better tailor advertising to their preferences. Various databases enable the development of applications and programs that the customer buys for his/her own use, and by using them he/she further contributes to the development of such a program. Trafficked data does not only include data enabling to identify a specific person, such as his/her name, age, approximate location, etc. Entrepreneurs are particularly interested in the data on the person's search on the Internet, what topics interest him/her, what products he/she buys, which services he/she uses. This information is then processed by data scientists, a thorough analysis is performed, and a marketing plan is built on it. And every single click of an Internet user is recorded and then processed in this way.

As described above, in the digital environment data is collected not only on the basis of direct submission by the user, but also through so-called cookies. The data is provided to the subject directly, if the user of the internet interface fills in a form, creates an account on a website, etc. These usually include personally identifiable information, and sometimes actively choosing certain preferences. In contrast, cookies contain records of how an Internet user acts, what information he/she searches for, what he/she likes, what and how he/she buys. By analysing such data, researchers can reveal unexpectedly personal information, often information that the user does not know about, and subconsciously makes the choice. European Union citizens are covered by Directive 2009/136/EC, which requires platform operators to inform users that this data is being collected and further processed, and the user must explicitly consent to this (despite the fact that many users are denied access to the web if they decide not to agree). In both cases, however, users should be explained in detail how their data will be further used and what they can expect as a result of their processing.

From the above it is clear that data trading will occur more and more often. The first problem is the question of who is the owner of the information provided about users in this way - the website operator, its owner or the author of the part of it that collects this data and passes it on for processing? This, however, falls into the category of business relations, which will be governed by a contract between the parties. However, for tax

4 See on this topic, for example, Yuval Noah Harrari: Homo Deus. 
administrations, this information can be crucial and non-transparent due to the internal organisation of the relationship. It will require considerable effort not only to identify such a person, but also to find his/her localisation. On the one hand, the fact that the sale of such data is taxed could simplify the situation. As stated in the draft of the Czech Act No. 89/2019 Coll. on Digital Tax, "therefore, a tax on selected digital services is not a tax on the collection or use of data collected by companies for their internal purposes or the sharing of data collected by companies with other parties free of charge" (the Digital Tax Directive proposal). Then we would assume that the obligated entity is the party to the contract that provides its database to another entity and accepts payment for it. The bill further stipulates that "the tax on selected digital services is focused on the transfer of data obtained from highly specific activities (user activities on the digital interface)." It also remains unclear, and this is crucial for these purposes, where the sale of data begins - i.e. how they get to the seller's possession in the first place. This brings us back to the question asked at the beginning of this paragraph: who is the owner of the user information collected in this way?

The Ministry of Finance of the Czech Republic describes the digital tax as an indirect tax (the OECD and the EU do not comment in this regard). In order for an entity to become a taxpayer, it must meet several conditions: (Ondroušek, 2019)

1. a separate legal entity or unit without legal personality, if the total revenues in the relevant period are higher than EUR 750,000,000 and at the same time the total amount for taxable services provided for the relevant period is higher than CZK 50,000,000 (EUR 1,830,600)

2. entity of a group, if the total amount for the provided taxable services for all members of the group carried out in the relevant period belonging to the Czech Republic is higher than CZK 50,000,000 (EUR 1,830,600)

The draft of the Czech Digital Tax Act characterises an entity also as 'legal persons or units without legal personality' (the Digital Tax Directive proposal). It follows from the above that a legal person will be liable only when it generates a significant profit on the basis of a taxable supply, and which has achieved a certain position in the market. However, such corporations often create value - i.e. the basis for the provision of some of the above services, in a completely different place than the taxable supply ultimately takes place.

Corporations of this size often have units in different states. Each such unit often performs different tasks. When units work together, they generate some value that they pass on to the corporation's customers, often in completely different states. However, these customers enter into a contract with units that are not those that in fact contributed to the creation of the traded value. So far, it is still relatively simple, but there are corporate schemes, which on the outside appear to be the cooperation of mutually unjustified entities. Given the fact that each state has a different legislation regarding the legal personality and the designation of company units, as well as a different tax legislation, it may be unclear when the surveyed corporation creates the value in question. Units with different job descriptions also keep different records of their activities and transactions. The combination of these facts with different tax jurisdictions makes it very difficult to determine whether an obligation to pay a tax has arisen, even for the liable entity itself. 
In addition, there is room for tax optimisation and aggressive tax planning, where entities benefit from this lack of clarity. A common feature of these procedures is that corporations usually act within the legal provisions even in such actions. However, they exploit gaps in the law, where the legislator either failed to adjust some important actions or could not do so because it would disadvantage entities with a weaker economic position. In the case of tax optimisation, it is mainly the spillover of profits between individual units established in different countries, or various internal relations, such as loans, sales, etc. (here we can also talk about the use of so-called tax havens). Aggressive tax planning is the refined use of all possible benefits resulting from tax regulations and the application of the laws of different territories so that the tax liability is minimised as much as possible. One example is the so-called hybrid arrangement effect. It is about creating an artificial structure that uses different tax systems so that double deduction is possible. This may be a double deduction of the loss, once in the source country and a second time in the country in which the company has its registered office. There may be double non-taxation of interest, where in one country interest costs are deducted from the tax base and in another country interest is not included in the taxable income, but also the use of a situation where the value arises in one state in which the company operates, but in the state registration, such value is exempt from tax.

From the above it is clear that there is a certain difference between various service providers. As described in the introduction to this article, all the above implies that there is a lack of certainty as to who the taxable person is. We can call this phenomenon tax absence. However, this is not the will of the taxpayer, who, although he/she may want to take advantage of this situation, did not cause it. What makes a subject a taxable person is not the supply or performance of other conditions, but the law itself. An unequal legal relationship arises between the legislator and the tax subject. Therefore, it is the responsibility of the legislator to create laws so as to provide the liable person with sufficient certainty about his/her rights and obligations, and to cover all possible situations in which the obligation to pay tax should arise. (Drywa, 2017) Given the fact that taxes represent a government interference with a person's fundamental property rights, it is very important that the quality of tax laws be at a high level. In addition, these laws are among the most frequently amended, so the legislator must be particularly prudent and ensure that the legal certainty of entities is not compromised.

We have a relatively wide range of entities that may be liable to digital taxation. The essential problem is that if we have difficulty determining who the liable entity is, it will be all the more difficult to find the right tax jurisdiction. This obviously leads to a potentially incorrect application of the law and the impoverishment of the state where the taxation was supposed to take place. This creates legal uncertainty on both sides - both for the liable entity and the tax administrator. The situation may escalate to the above-mentioned tax evasion. This is due to the fact that, unlike the tax administrator, the liable entity has the motivation to use this gap in the law and find such a solution that would help it to reduce the tax liability to a minimum. Due to the insufficient quality of the legal regulation, he/she will be able to remain within the limits of the law during such conduct and will not be punishable. 
If the introduction of the digital tax aims to, next to other issues, fill in the lack of funding in state budgets, ${ }^{5}$ it is essential that it will be properly regulated by the laws of each jurisdiction. Furthermore, as there is often an international element which is an important factor of potential tax evasion, it is also necessary to achieve a certain standard of harmonisation at the level of international organisations. That should be a priority.

The need to introduce a digital tax is one of the consequences of the advanced phase of globalisation, which has been mainly achieved due to digital means of communication. It is therefore almost self-evident that the international element will be one of the hallmarks of a taxable transaction. The Organisation for Economic Co-operation and Development (OECD) deals with the issue in cooperation with the G20 countries. The main goal of the OECD is to solve the problem of low transparency in the taxation of digital companies and of the use of gaps in national tax systems. (OECD, 2019) The European Union is also coming up with a solution, which is currently in preparation: the above-mentioned Digital Tax Directive, which aims to harmonise the legislation of this tax in the individual Member States. Cooperation between the two organisations is rather problematic, as some Member States fear that if the digital tax is regulated only for the territory of the European Union, it will lead to the relocation of companies such as Google or Facebook, (Elčić, 2019) which would mean major economic losses. Therefore, a global solution is preferred.

However, reaching agreement at the global level is a great challenge, both in terms of discussions between states and in terms of time. While some Member States of the European Union (e.g. Austria or Spain) has been operating with the digital taxation for several years, in other countries (the Czech Republic, Slovakia) its introduction is still being prepared. In a group such as the European Union, it is, of course, undesirable for such significant differences in tax systems to arise. This was probably the main motivation for the Union to take action in this direction, despite the risks outlined above. Another attractive factor is the overall increase in the economic level of the entire group, thanks to increased transparency and improved competitiveness of smaller companies. (Vodák, 2018) In the current situation, large companies with a large number of users pay significantly lower taxes than digital companies with a user base in one or two countries. On the other hand, some states fear that this effect will not be achieved, as companies will have to charge for some of their services to the general public, which are still routinely free, in order to be able to offset the loss of funds paid to the state coffers. (Štípek, 2018) The rapid variability of business in the digital environment can also be risky. According to the Commission, a digital services tax, proposed in 2018 as a short-term solution, would generate annual revenues of around EUR 5 billion in the Union and reduce the fragmentation of the single market. ${ }^{6}$

A certain intersection between the OECD and the European Union approach may be projected in the Anti-Avoidance Directive (hereinafter ATAD). It was adopted on the

In the Czech Republic, the annual tax revenue is estimated at CZK 2.4 to 6.6 billion. See Právní rozhledy, Vol. 27, (2019) No. 15-16, Annex Legislation p. II.

6 COM/2018/0148 final. The Commission Communication Time to implement a modern, fair and efficient standard for taxing the digital economy states that "companies with digital business models pay less than half the tax rate for companies with traditional business models, with an average effective tax rate of $9.5 \%$ compared to $23.2 \%$ ". 
basis of long-term negotiations at OECD level and builds on them. It thus has a much wider international impact on entities operating not only inside the European Union but also outside it. (Radvan et al. 2016) The ATAD is a directive aimed at coordinating the procedures of national governments and tax administrations so that businesses operating in the territory of two or more EU Member States, or non-EU countries, do not use different tax codes for tax evasion in a country where it should be taxed, even though it may not be the most advantageous for them. (Hrubý, 2016) Two of its pillars will then be directly relevant to the effectiveness of the Digital Tax Directive:

- rules for dealing with hybrid structures (discrepancies), and

- rules for controlled foreign companies.

The so-called hybrid discrepancies occur in situations where revenues and expenditures arising from the entrepreneur's foreign activities are qualified differently by the various legal systems concerned. The functioning of the digital tax in only some countries serves as a good example. While in one of the countries concerned the revenue from the provision of digital services may be considered the item of the total revenue of the corporation for selling its services, in the other country it may be assessed, for example, as renting digital space for advertising, royalties for code creation, etc.; different rates will then be applied. In the absence of common rules determining which types of services are subject to which tax and under what conditions, and in particular the rules for determining in which place the value in question arose, the liable entity has a choice. It will thus adapt the taxable supply to the regulation which is more favourable to it, even though in fact it has a legal relationship with a country with a different regulation.

In case of companies where there is a subsidiary hierarchy between units located in different states, there is a different kind of tax optimisation. This usually includes the relationship between the controlling company and the controlled one, and it does not appear to be a single company. As a result of the subsidiary relationship, they should be considered a single corporation. Values move between these units in such a way that they appear to be transactions between completely different entities. This again is an easement to the search for such tax rules that are most advantageous for the entity, and thus to an outflow of funds that would belong to the budget of the state in whose territory the value in question actually arose. This happens most often via intra-company loans, investments of the controlling company in the controlled company, handling of receivables, etc.

The re-launched Common Consolidated Corporate Tax Base Directive (hereinafter CCCTB) is expected to address both issues. Although it has been introduced in the past, neither the business environment in the European Union nor national regulations were ready for it at the time. Following the adoption of the ATAD Directive, there was scope for its recast and adaptation to current market conditions. The CCCTB aims to consolidate the tax base of corporations which have branches located in two or more Member States. It intends to achieve this by several methods depending on the nature of the relationships between these units:

- full consolidation method:

- the consolidating entity exercises a decisive influence in the consolidated entity

- the consolidating entity excludes financial investments in the consolidated one 
- intra-company receivables and other property liabilities are excluded

- proportional consolidation method:

- the consolidated unit is controlled by two or more consolidating units together

- consolidating entities report a proportionate share of assets and liabilities

- intra-company receivables and other property liabilities are excluded

- equity method of consolidation:

- the consolidating entity does not control the consolidated entity, but has a significant influence in it

- the consolidating entity recognises, against securities, the following items:

- profit or loss in equivalence representing the share of profit or loss of the consolidated unit

- consolidation reserve fund representing the share of retained earnings of previous years of the consolidated unit

- intra-company receivables and other property liabilities are not excluded

The consolidated tax base is shared only if the result is positive, negative consolidated tax base is included in future consolidated profits. Finally, a relatively complex computational formula is applied.

However, sufficient prior tax harmonisation is a precondition for these procedures. In view of the fact that the calculations for the sharing of the consolidated tax base are carried out at the end of the accounting year of the whole group, it will be necessary for these periods to overlap for different countries. The European Commission intends to implement this directive in two steps. In the first phase, the calculation of the tax base will be harmonised so that it is approached in approximately the same way in all countries and thus undesirable differences do not arise. Important criteria are neutrality, equity, simplicity, enforceability, scope, income stability, public policy and the costs associated with reform. In the second phase, the consolidation itself is to be performed using the above methods.

\section{Conclusion}

At the beginning of this article, we introduced and explained the core of the problem and described it as a tax absence in relation to the digital tax. This phenomenon is mainly due to the fragmentation of tax regulation in different countries, and in today's globalised world it is not possible to expect companies not to expand abroad. This is all the more true for entities doing business in the digital environment, which often do not even have a physical base and branches. In such situations, it is easy to find the most advantageous tax regime or even avoid taxation altogether. A high-quality taxation system needs to be created for the activities of this type of business. The introduction of a digital tax, at least in the European Union, despite the above explained risks, seems to be a desirable solution that will bring the missing funds to state budgets and at the same time implement a greater 
degree of control over the activities and expansion of these entities. The previous paragraphs attempted to analyse the proposed legislative texts and to map the process according to which the person liable to pay the digital tax is to be determined. Based on the interpretation of some terms and by deduction, we found that there is a relatively vague spectrum of entities that can be designated as a mandatory entity. These can then be difficult to trace, especially when it is possible that they will often not even have a legal personality. Here then the question arises - is it possible to enforce the fulfilment of any financial obligations by an entity without legal personality? Who does bear the responsibility for it?

An ambitious goal - to solve the problem of tax absence - is set by the re-launch of the CCCTB Directive. If the essence is to calculate the tax base (in general) for the whole group together, and then to divide the tax liability proportionally between the individual units on the basis of a proportional formula, this could have the desired effect. As follows from the above, for digital tax, the subordination of the liable entity and the obligation itself under the tax jurisdiction will be a major problem. An entity without a legal personality can also be a subject to tax. At the same time, the nature of the performance allows for a high degree of localisation flexibility. The CCCTB Directive introduces a rule whereby the taxable values of all units in a group are added together, especially those located abroad. Ideally, the value should be taxed at the place where it was created. This is often not possible in case of digital services provided abroad, or it is not possible to determine such a place. If the tax calculated on the basis of the consolidated basis is distributed through the allocation formula, the funds collected will be fairly distributed among the states without the need for excessive administrative effort in order to apply the law of the administrative state to taxable transactions. However, problems may still arise here because some states lack legislation to consolidate entities located abroad. For example, in the case of the Czech Republic, this is addressed by the international accounting standards IAS 21. The somewhat legal philosophical question remains whether the accounting standards have sufficient legal force to be used in the field of international taxation. According to the Association of Industry and Transport of the Czech Republic, a long-term solution to the tax absence of modern digital companies linked to the CCCTB Directive could be to create a rule where the company will have to establish a so-called permanent virtual establishment, provided that at least one of the following criteria is met: annual revenues in a Member State exceed EUR 7 million; it has more than 100,000 users in one tax period; during the tax period, it concluded more than 3,000 business contracts for the provision of digital services with business users. However, in order for the problem to be truly solved, it is necessary to approach the solution with the knowledge that the development of digitisation is very dynamic and we can expect its expansion into traditional economic sectors in a very short time. In this context, it is necessary to focus on long-term solutions and cooperation of as many countries as possible, not only within the European Union and/or the OECD, but also, if possible, outside of these organisations. Although the CCCTB Directive offers a good solution to the problem of the indeterminacy of tax residence in relation to digital tax, I do not believe that this is a sufficiently effective and final solution. The hypothesis thus remains unconfirmed. 


\section{References}

Čejková, T. (2019). Život a daně digitálního nomáda [Life and Taxes of Digital Nomad]. In J. Schweigl, E. Tomášková, \& M. Janovec (Eds.), Cofola 2019 (pp. 38-47). Masaryk University.

Drywa, A. (2017). The quality of the law as a factor shaping the taxpayer's legal position. In M. Radvan, J. Gliniecka, T. Sowiński, \& P. Mrkývka (Eds.), The Financial Law towards Challenges of the XXI Century (pp. 366-378). Masaryk University. https://doi.org/10.5817/cz.muni.p210-8516-2017

Elčić S. (2019). Česko chystá vlastní zdanění Facebooku a Googlu. Evropská dohoda skončila fiaskem [The Czech Republic is Preparing its Own Taxation on Facebook and Google. The European Agreement Ended in a Fiasco]. https://bit.ly/2zG3Wli

Hrubý, Š. (2016). Nové směrnice EU proti vyhýbání se daňovým povinnostem [New EU Directive against Tax Avoidance]. https://bit.ly/2ZOp83b

OECD (2019). Tax and Digitalisation. Policy Note. https://bit.ly/2XbWPKw

Ondroušek, M. (2019). Overview of the Impacts of the Introduction of the Digital Tax. Institute for Politics and Society, Policy Paper. https://bit.ly/2ZQfJrR

Radvan, M., Mrkývka, P., Kappel, J., Schweigl, J., Liška, M., Neckáŕ, J., Snopková, P., Šefč́ík, M., Pařízková, I., \& Kouba, S. (2016). Důchodové daně [Income taxes]. Masaryk University.

Štípek, V. (2018). Rizika digitálních daní a možná řešení [Risks of Digital Taxes and Possible Solutions]. Svaz průmyslu a dopravy České republiky [Confederation of Industry and Transport of the Czech Republic]. https://bit.ly/2zyq1CA

Vodák, P. (2018). Výzvy spojené se zavedením digitální daně v EU [Challenges Associated with the Introduction of a Digital Tax in the EU]. https://bit.ly/2AnWTO5

\section{Legal references}

2009/136/EC Directive of the European Parliament and of the Council amending Directive 2002/22/EC on universal service and users' rights relating to electronic communications networks and services, Directive 2002/58/EC concerning the processing of personal data and the protection of privacy in the electronic communications sector and Regulation (EC) No 2006/2004 on cooperation between national authorities responsible for the enforcement of consumer protection laws. https://bit.ly/2XcaTDC

COM/2016/0683. Proposal for a Council Directive on a Common Consolidated Corporate Tax Base (CCCTB), EurLEX. https://bit.ly/3cfLzAQ

COM/2018/0148. Proposal for a Council Directive on the common system of a digital services tax on revenues resulting from the provision of certain digital services, EurLEX. https://bit.ly/3deAOQV

Council Directive (EU) 2016/116 laying down rules against tax avoidance practices that directly affect the functioning of the internal market. https://bit.ly/2zG10Fi

Explanatory Memorandum to Act Nr. 89/2019 Coll. - Czech Tax on Digital Services Proposal (2019). https:// bit.ly/2Xh9g7X 